\title{
Development induced Displacement
}

\section{Raoof Ahmad lone}

Research Scholar, Centre for Studies in Economics and Planning, School of Social Science, Central University of Gujarat, Gandhinagar, India.

\begin{abstract}
To every political policy, economic and development project, on the one side there is welfare in terms of benefits reaped by some section of population and on the other side it increases sorrows and despair to others. Each year, millions of people around the globe are relocated and resettled away from their homes, lands and livelihoods in order to make way for large-scale development projects such as dams, reservoirs, power plants, roads, plantations, urban renewal, and oil, gas, and mining projects. This forced relocation is known as development-induced displacement. Development has uprooted people not only from homes, but homelands to which they may have been tied by old ancestral bonds. Displacement deprives people from many things, some of them are fundamental to their lives, including homes, productive assets, culture, livelihoods, environmental conditions suited to their skill and practices, community networks and sense of belonging. The determination of the extant of deprivation, plight and sufferings depends on what they face at new location and resource they enjoy there. If proper compensation is being provided in terms of economic incentives and rehabilitation then both the developmental project and displacement can be justifiable. The paper will provide an overview about development induced displacement cases, how many people it affects, what are primary causes and main impacts. It will also highlight certain recommendatory measures for sustainable development and welfare oriented development enjoyed by all in equal sense.
\end{abstract}

Key Words: Development; Displacement; Land; Projects; People

\section{Council for Innovative Research}

Peer Review Research Publishing System

Journal of Social Science Research

Vol3, No.2

editor@jssronline.com

www.cirworld.com, www.jssronline.com 


\section{Introduction}

The proper connotation of the term development is the overall welfare increment of the society in every aspect whether economic, political and social. Development refers to the situation where both material and quality living standard of masses will increase. The most fundamental goal of economic development seems to be to advance the welfare and wellbeing of the people. But the process of development, the world is proceeding with, had created lot of sufferings and miseries to a vast sections of population. At the name of development many developmental projects had been developed and constructed in the form of dams, power projects, railway lines, economic processesing zones and many others on the private property and the holders were displaced at the name of some economic remunerations and overdues, those in the future life does not mitigate their economic and other sufferings.

Each year, millions of people around the globe are relocated and resettled away from their homes, lands and livelihoods in order to make way for large-scale development projects such as dams, reservoirs, power plants, roads, plantations, urban renewal, and oil, gas, and mining projects. This forced relocation is known as development-induced displacement. Development has uprooted people not only from homes, but homelands to which they may have been tied by old ancestral bonds (Hoshour and Jennifer 2007). Displacement deprives people from many things, some of them are fundamental to their lives, including homes, productive assets, culture, livelihoods, environmental conditions suited to their skill and practices, community networks and sense of belonging.

Typically, economic development policies and practices promoting growth have been advocated and emphasized for the development goal of reducing or eliminating poverty: economic growth is to considered, would provide employment for the poor, purchasing power for consumers to buy what poor people could produce and a tax base with which governments could provide essential services to the poor, and built social and economical infrastructure, including schools and hospitals for making the poor and deprived sections more competitive in job markets and hence then enhance their earning capacity. The developmental practice and policies framed during the past century and the decade of current century, servicing these goals, is far from the ideals (Penz et al). So there is a paradoxical situation, the theoretical framework of development emphasizes on the overall empowerment and wellbeing of humankind while as the practical and real practice of development initiated by the construction of various economic and social infrastructure causes mass scale forced displacement and miseries and sufferings to the displaced persons.

During the 1990s, development induced displacement emerged as a major concern and a challenge to the sustainable economic development and stability of economic regimes and policies. The concern arouse because of dramatic rise in development induced displacements in the 1970 s and 1980s strengthened mainly by global infrastructure boom and ruthless developmental policies coupled with painful and disastrous outcomes in resettlement experiences. A corresponding retaliation to public policies and economic regimes in the form of protests, campaigns and resistance emerge, questioned the authority of policy framers and planners at different levels. The developing hurdles and resentments necessitated fresh insights to the life worlds of affected people (Dwivedi).

\section{Displacement Conceptualization}

Displacement is described as dislocation of people from their native place and region. It often exacerbates rather than mitigates economic insecurity, helplessness and alienation. This could mean loss of economic livelihoods and communities (Siddiqui 2012). Looking to background, it can be said, that migration is of two type's voluntary migration intended due to some economic, educational and social reasons in order to have betterment and enhance standard of living. Another is forced migration when people are forced and involuntarily they have to vacate from their residential places, economic setups, political and social systems. This type of migration better termed as displacement resulted to huge economic imbalance, unrest and insecurity in a country and world over due to the over linkage of environment and openness of economies. Displacement of human populations from the natural habitats results in a host of socio-economic impacts. 
The voluntarily migration is mainly due to some economic consideration like high wages, better employment, business opportunities, good standard of education, urban style of living and modernization in skills and is intended intentionally for the welfare and development consideration. But forced migration and displacement occurred due to some social, political crisis, armed conflict, human rights violation, natural disasters, construction of some projects like dams, power projects, railway lines, mineral extraction, processing zones etc. Forced migration and displacement again can be looked in several ways one is due to natural causes which cannot be stopped, other is due to some political unrest i.e. wars, human rights violation, conflicts the solution lies in well designed political and social policies and regimes (Rwamatwara 2005). The third type of forced migration takes in course due to the construction of some developmental projects which are intended into construction only for welfare and development of masses and overall economy but there is lot of crises and sufferings to the people who are displaced due to the construction of such projects, this is a paradoxical situation. In the paper the displacement originated from the construction of developmental projects like dams, power projects, etc. is dealt with and the paper is based on secondary sources and data collected from world development reports, various published papers and articles. The main objective of paper is to locate the figures of displacement caused at the name of some prominent developmental projects in India. Further to assess the impacts and measures taken for the wellbeing of displaced people.

\section{Development oriented Displacement}

The issue of displacement is seen as necessary evil. In order to construct industries, infrastructure such as dams, mining, roads, and power projects, which are intended to serve greater welfare, certain land and property is required, which will disturb the life ecosystem of the affected society. Displacement is seen as the result of a model of development that enforces certain technical and economic choices without giving any serious consideration to those options that would involve the least social and environmental costs (Bartolome et al. 2000).

Development is a major driver of displacement and a challenge for humanitarian actors. The construction of dams, for example, forces people to move from areas to be flooded. When governments set aside land for parks or urban renewal, people are also forced out. And even when governments plan resettlement policies, affected communities are almost always worse off (Siddiqui 2012).

No precise data exists on the numbers of persons affected by development-induced displacement throughout the world. Unlike for refugees and internally displaced persons (IDPs), there are no institutions or publications dedicated to tracking and estimate overall development induced displacements, either at the global or at national levels. For an indication of magnitude, most scholars, policy-makers, and activists rely on the World Bank Environment Department's (WBED) estimate that roughly presents, that 10 million people are displaced each year due to dam construction, urban development, and transportation and infrastructure programs (Stanley 2004). This number is shockingly high, but it still fails to account a large numbers of the displaced persons. As pointed out in the introduction, the purview of displacement here just refer only to persons physically ousted from legally acquired land in order to make way for the planned developmental projects.

Development has uprooted people not only from homes, but homelands to which they may have been tied by old ancestral bonds. The removal of people to make room for roads, railway lines, industrial plants, harbours and urban expansion and redevelopment has been evident at every centre of the world. The extent of world displacement level is a bit shown by the below given table 1.1

\begin{tabular}{|l|r|r|r|r|}
\hline \multicolumn{1}{|c|}{ Region } & \multicolumn{2}{c|}{ Projects } & \multicolumn{1}{c|}{ Percentage } & \multicolumn{1}{c|}{ People } \\
\hline Africa & 34 & 23.3 & 113,000 & 5.8 \\
\hline South Asia & 29 & 19.9 & $1,024,000$ & 52.1 \\
\hline
\end{tabular}




\begin{tabular}{|l|r|r|r|r|}
\hline East Asia & 58 & 39.7 & 588,000 & 30.0 \\
\hline Europe & 5 & 3.4 & 27,000 & 1.4 \\
\hline Middle East/North Africa & 7 & 4.8 & 32,000 & 1.6 \\
\hline Latin America & 13 & 8.9 & 180,000 & 9.1 \\
\hline Total World Bank & 146 & 100 & $1,963,000$ & 100 \\
\hline
\end{tabular}

Table1.1: World Development Projects Active in1993 and Scale of Displacement of Persons Source: World Development Environment Department report 1996.

The figures in table1.1 reflect the number of developmental projects in absolute terms in column 2, and percentage of development projects in column 3. Then number of displaced persons is shown in column 4 and percentage of displaced persons in column 5. It shows that higher number of projects stands in East Asia (ASEAN nations) that is 58 developmental projects, sharing 39.7 percent of total. The number of developmental projects constructed in Africa stands at second position with 34 projects, sharing 23.3 percent. Then comes the South Asia's (India, Bangladesh etc.) position with 29 developmental projects, sharing 19.9 percent of total projects. It is followed by Latin America with 13 projects, sharing 8.9 percent of total projects constructed during early 1990s. Looking to the scale of displacement, it is South Asia which accounts 1024000 persons who are displaced due to the construction of developmental projects, sharing 52.1 percent of total displaced persons during the early 1990s. East Asia ranks second with 588000 displaced persons accounting 30.0 percent of total displaced persons. This time it is Latin America which ranks at third position sharing 9.1 percent of displaced persons during early 1990s. The reason behind high displacement in South Asia is lack of any specific resettlement mechanism policies within India, Bangladesh, Pakistan etc. While as in East Asia, China has a sound policy of resettlement along with Hong Kong and Taiwan.

\section{Types of Developmental Projects and level of Displacement}

Displacement or the involuntary and forced relocation of people has come to be acknowledged as among the most significant negative impacts of large water resources development projects such as dams. It is estimated that nearly 60 million people have been displaced worldwide due to the reservoirs created by large dams (McCully, P. 1996). A World Bank review of 192 projects worldwide for the period 1986 and 1993 estimated that 4 million people were displaced annually by the 300 large dams (on an average) that entered into construction every year (WCD 2000).

The primary causes of displacements induced by development over the past half century include: water supply (dams, reservoirs, irrigation); transportation (roads, highway, canals); energy (mining, power plants, oil exploration and extraction, pipelines); and With rapid urbanization occurring on a global scale, projects aimed at providing transportation, housing, electricity, water, sanitation, and other services to rapidly growing cities have emerged as major drivers of displacement. Urban renewal and beautification schemes, often aimed at making cities attractive to tourists, have displaced the people living in the near vicinities. It is likely that the number of people affected by development induced displacement will continue to grow in the coming years; with urban growth rates exceeding six percent annually, the UN estimates that more than two billion people will be living in large cities with populations of more than one million people by the year 2025 (Hoshour and Jennifer 2007).

\section{Dam Construction and Displacement}

Constructions of dams, hydropower plants, irrigation projects, artificial reservoirs and canals have created lot of displacements over the time throughout the world at mass scale. Dam building is the greatest cause of developmentinduced displacement worldwide. According to a report of the World Commission on Dams, the construction of large dams has led to the displacement of some 40 to 80 million people worldwide (Terminski 2013). Irreversible flooding of vast areas 
and the need for resettlement of entire communities in remote areas has a much greater social impact than many other causes of displacement. Construction of roads and urban development do not involve the total transformation of the previously inhabited areas, the displaced people can live in the immediate vicinity of their previous residence and are better able to maintain their customary economic model, existing social customs and cultural traditions. In the case of people forcibly resettled due to construction of dams, restoring livelihood and adapting is a much more difficult and longterm process. Dams have been the biggest source of destruction of habitat and displacement of people in the last 50 years (Ray 2000).

According to the World Commission on Dams, construction of dams was the sole cause of $34 \%$ of development induced displacements in China between 1950 and 1990. According to Taneja and Thakkar (2000), the construction of dams alone displaced between 21 and 40 million people in India (Terminski 2013).

\section{Urban Infrastructure, Transportation and Displacement}

Construction of roads, highways and rail transportation is currently, along with construction of dams, one of the causes of development induced displacement on the largest scale. According to the Bank wide Review of Projects Involving Involuntary Resettlement, transportation is the direct cause of 24.6 percent of all development induced displacement in World Bank-financed projects active in 1993. Development of urban infrastructure is the cause of $8.2 \%$ of resettlement worldwide. This problem to a greater or lesser extent affects most countries in the world. The Jabotabek urban development project in Indonesia, which involves widening of roads in Jakarta, displaced between 40,000 and 50,000 people (Terminski 2013). The World Bank Environment Department has estimated that 60 per cent of development induced displacement every year, about 6 million people is a result of urban infrastructure and transportation projects (Stanley 2004).

Displacement caused by development of transportation is extremely difficult to avoid even in developed countries. The highway construction project in Boston has association with the displacement of several thousand people. In contrast to the construction of dams, development of roads has much slighter social consequences.

Urbanization infrastructure mostly includes expansion of urban areas, water supply projects, development of urban transport, etc. Water supply projects are another important cause of large scale relocations within urban space. As pointed out by Professor Michael M. Cernea, the single displacement caused by urbanization processes affects fewer people than the construction of dams. Displacements associated with urbanization are more numerous than those associated with the creation of dams. However, due to the high population density in urban areas, the number of people displaced per unit of area by projects of this kind is larger than the proportion displaced by a single dam (Terminski 2013).

\section{Natural Resource Extraction and Displacement}

This type includes in its domain the activities related with the exploration and extraction of minerals and metals like oil, coal, lignite, iron etc. No proper cumulative or annual statistics are available on the number of people displaced by natural resource extraction projects world-wide; however, evidence and figures from World Bank projects suggest that displacement in such projects is much lower than in many dam and urban renewal and development projects.

Table 1.2 will give a detailed figure about the project wise extant of displacement until 1993. It shows that about 66.4 percent of total persons displaced by the construction of several development projects are mainly due to dam and irrigation canal construction throughout the world. Then urban infrastructure and transportation accounts 22.6 percent of total development induced displacement.

Table 1.2: Project wise (active in 1993) displacement of people

\begin{tabular}{|l|l|l|}
\hline Category & Persons total & Percentage \\
\hline Dams, irrigation canals & 1304000 & 66.4 \\
\hline $\begin{array}{l}\text { Urban infrastructure (Sewerage, } \\
\text { transportation) }\end{array}$ & 443000 & 22.6 \\
\hline
\end{tabular}




\begin{tabular}{|l|l|l|}
\hline Extraction (mining) & 94000 & 4.8 \\
\hline Others & 122000 & 6.2 \\
\hline Total & 1963000 & 100 \\
\hline
\end{tabular}

Source: Stanley Jason 2004.

\section{Development induced displacement in Indian Context}

India's economic liberalisation also known as New Economic Policy was launched in 1991, when Indian economy went for new economic reforms. The major policy change was growth centered focus. It did not make any reference to long standing problems of the Indian economy such as poverty, malnutrition, unemployment, ill health, illiteracy and environmental degradation etc. The speed of developmental project construction got momentum as with the adoption of neoliberal reforms; the foreign investors have increased their presence in India. And various collaboration and joint ventures projects have been launched. For example, in recent years as many as 341 SEZs have been approved and set up across India.

There is a disagreement over exact figure of displaced people. It seems likely that not less than 40- 50 million people have been displaced. Various studies on displacement point out that earlier phase until 1980 was marked by meagre compensation towards the affected people and lack of any attempt to understand the issues of rehabilitation of the displaced people. Most of the affected people were from poor sections of society and with the displacement they were further marginalized and gripped in vicious circle of poverty and sufferings due to loss of their livelihoods (Siddiqui 2012).

The involuntary displacement of people due to acquisition of their land for developmental activities throughout India is a major issue. This resulted in widespread protests across the country. People began to protests, for example, major projects such as Sardar Sarovar, Salient Valley, the Manglore Thermal Power, the Dabhol power, Maha Mumbai Special Economic Zones (SEZ), the Nandigram SEZ, the Singur Tata Motors and so on led to great resentment among people that were displaced and affected by these projects. The Sardar Sarovar project has affected nearly 300 villages, with 163 000 people have been displaced and among them tribal population has been severely affected (Parasuraman 1999).

The Upper Krishna irrigation project (i.e. dams and reservoir) displaced about 300000 peoples.

Loss of livelihoods and displacement has become a recurring feature of Singrauli region of Madhya Pradesh state mainly due to construction of dams, power and mining since 1960s. Displacement in the region began first by the construction of Rihand dam and Govind Sagar Reservoir in the 1960s, fuelled by Thermal power projects in 1980s, which led to expansion of coal mining in the region. All these activities have generated a series of displacement and loss of livelihoods of the people in the region (Sharma and Singh 2009).

Recent years have witnessed lot of displacements induced by development in the states like Gujarat, Haryana, Jharkhand, Madhya Pradesh and West Bengal due to the acquisition of land for SEZs for attracting millions of US dollars on nearly half-million acres of land. It was also claimed that these investments would create more than half million jobs, but due to high mechanised and automation the job creation was far less than expected (Patnaik 2007).

The figure about the scale of displaced persons in the various states due to the construction of various projects is presented by the below give table 1.3. Table presents the project name and the state located in along with number of displaced persons.

Table 1.3: Different projects and scale of displacement in India

\begin{tabular}{|l|l|l|}
\hline Name of project & State & Number of displaced persons \\
\hline Sardar Sarovar & Gujarat & 200000 \\
\hline Ukai & Gujarat & 52000 \\
\hline Karjan & Gujarat & 11600 \\
\hline Maheshwar & Madhya Pradesh & 20000 \\
\hline Bodhghat & Madhya Pradesh & 12700 \\
\hline
\end{tabular}




\begin{tabular}{|l|l|l|}
\hline Chandil & Bihar & 37600 \\
\hline Koel Karo & Bihar & 66000 \\
\hline Maithon and Panchet & Bihar & 93874 \\
\hline Mahi Bajaj Sagar & Rajasthan & 38400 \\
\hline Polavaram & Andhra Pradesh & 150000 \\
\hline Ichampalli & Andhra Pradesh \& Maharashtra & 38100 \\
\hline Tultuli & Maharashtra & 13600 \\
\hline Bhakra & Himachal Pradesh & 36000 \\
\hline Pong & Himachal Pradesh & 80000 \\
\hline Upper Indravati & Orissa & 18500 \\
\hline
\end{tabular}

Source: Siddiqui 2012.

Forced displacement occurred due to the need to build dams, transportation, power generation, urban development and so on. It is claimed that such projects creates employment and improves services which in turn leads overall development and welfare of population. However, it also displaces people from their land, community and cultural heritage and raises major issues social justice and equity. The government of India admitted that several million people displaced by dams, mines, industries, power plants etc. and are still waiting for rehabilitation. The developmental projects are always put forward as development for national interest and the communities, who lost their livelihoods and bear up lot of sufferings for so-called 'greater good' and national interest, would be making this sacrifice to benefit the entire nation.

\section{Impact and effects of forced displacement}

Displacement of human populations from the natural habitats results in a host of socio-economic impacts. It often exacerbates economic insecurity, helplessness and alienation. Displacement also resulted in the loss of economic livelihoods and communities, raises major issues social justice and equity. Displacement has created several issues like: Landlessness; joblessness; homelessness; marginalisation; food insecurity; community disarticulation; loss of access to common property resources. Land being a basis of people's productive system in agrarian society, if it is confiscated and not replaced by steady income generating employment, it would lead towards impoverishment and the interlinked social, political and economic disturbances and violations (Cernea 1999 \& 2000, Siddiqui 2012).

Poorly implemented resettlement plans, unaccompanied by adequate compensation for lost assets and mechanisms of social support, lead to long-term or even irreversible deterioration in the conditions of large communities. Displacement resulting to a mainframe of problems related to environmental destruction or degradation, evictions or evacuations resulting from public disturbances, natural or human-induced disasters, tension or unrest, internal, international or mixed conflict (having domestic and international dimensions) and public emergencies, domestic violence, and certain cultural and traditional practices often take place without regard for existing human rights and humanitarian standards, including the right to adequate sheltering and residence (HCR, UN report).

Lot of evidence is presented by India regarding the displacement and violation. The protests staged by civil society and peoples against land acquisition have been growing in recent years. These protests and violence increasingly question the so-called "greater good". The protest in Bhatta-Parsaul of Noida in Uttar Pradesh state tells us about the condition and centre of violence provoked by an attempt to displace the farmers. In fact, whether it is Bhatta-Parsaul in UP, Nandigram in West Bengal, Chattisgarh, Jharkhand, Andhra Pradesh, Kerala and in Tamil Nadu all pointed towards the need to examine the matter immediately. The violence witnessed in Nandigram in West Bengal state in 2007, where 14 people were killed while protesting the notification of land acquisition of 25000 acres of land under Land Acquisition. Protests and violence broke out in Haryana over the Tata Nano land acquisition demand and related matter in the recent past (Stanley 2004, Siddiqui 2012). 
The displacement based on developmental projects leads to economic insecurity, due to loss of previously possessing resources, social insecurity, due to loss of community and society they were adjusting and living with, health insecurity, due to their deprivation form basic amenities and facilities, food insecurity because of lack of avenues to produce their own food stuffs, environmental insecurity because of over exploitation of natural resources at the disposal of displaced societies, cultural insecurity, due to varied culture and lack of adjustment and political insecurity because of recurrent agitation and protests staged by victims of developmental projects (Caspary 2007,Terminski 2013).

Measures for mitigating and minimizing the displacement problems

The industries and developmental projects need to be promoted, but at the same time, the government must ensure that its destructive effects upon the people, who faces dispossession are minimised. But that cannot be realized if corporate industrialisation is only available option, under such regime, State's leading role is being replaced by market. On the name of "virtues of free-markets" and competition, the monopolists are given enormous power to undermine very competition they are claiming to establish. The government must adopt some mechanism of land grabbing and the compensation provided that is viable both economically and socially to the affected and displaced society.

There should be proper economic estimation of all the assets which are being confiscated and destroyed by the government or private organisation for constructing projects. Consideration should be given to all economic and shadow and opportunity value of all resources which the displaced persons have to sacrifice. Every evicted displaced and dislocated person should be provided basic shelter facility, essential food, potable water and sanitation, mandatory medical and healthcare services, livelihood sources, education facilities for children, protection of human rights and also some entertainment and amusement facilities (Hoshour and Jennifer 2007).

\section{Conclusion}

Looking to regime prevailing in the world today and also in the past, it is evident that development induced displacement is inevitable. The construction of projects like dams, power houses, irrigation canals many other infrastructure is very much important and basic requirement for development both in economic and social sense. However the impacts of developmental project construction are multivariate and disastrous and are expelling larger section out of their residential places means reducing their development and growth avenues. So the is a paradoxical situation. Both the things have to go as a retaliatory mechanism. Now only possible way out to mitigate the negative impacts and reduce the sufferings is responsive government. There should be proper compensation and rehabilitation mechanism adopted for displaced persons. Medical, sanitation and educational facilities should be provided to dislocated people hence they will not feel the ignorance on the part of developmental gains proceeding to rest of the population in the world.

\section{References:}

A. Bartolome L.J., De Wet C., Mander H., Nagraj V.K. (2000), "Displacement, Resettlement, Rehabilitation, Reparation and Development", Cape Town, South Africa: Thematic Review I.3, World Commission on Dams, http://www.dams.org/kbase/thematic/tr13.htm.

B. Caspary Georg (2007), "The Impacts of Development-induced Displacement on Human Security, A Study on Dam Finance", Human Security Journal, Vol. 4.

C. Dreze J., Samson M., and Singh S. (1997), "The Dam and the Nation: Displacement and resettlement in the Narmada Valley", Delhi: Oxford University Press.

D. Hoshour Kate and Jennifer Kalafut (2007), "A Growing Global Crisis; Development-induced Displacement \& Resettlement", International Accountability Project, Issue Paper.

E. Kalim Siddiqui (2013), "Development and Displacement in India: Reforming the Economy towards Sustainability" IOP Science, IOP.Org.

F. McCully P. (2001), "Silenced Rivers: The ecology and politics of large dams", London: Zed Books. 
G. M. M. Cernea (1997), "Hydropower Dams and Social Impacts: A Sociological Perspective", Research Paper, World Bank.

H. Parasuraman, S. (1999), "The Development Dilemma: Displacement in India”, Basingstoke: Macmillan.

I. Patnaik Prabhat (2007), "In the Aftermath of Nandigram", Economic and Political Weekly, Vol. 42 (2).

J. Ray Parshuram (2000), “Development Induced Displacement in India”, Sarwatch Vol. 2 (1).

K. Rwamatwara Egide (2005), "Forced migration in Africa: A challenge to development", Stichproben, Afrikastudien No.8.

L. Sharma, R.N. (2003), "Involuntary Displacement: a few encounters”, Economic and Political Weekly, Vol. 37 (9).

M. Sharma R.N. and Singh S.R. (2009), "Displacement in Singrauli Region: Entitlements and Rehabilitation", Economic and Political Weekly, Mumbai.

N. Siddiqui Kalim (1993), "Large Dams and Environmental Problems", Dag og Tid, (in Norwegian), 25th February, Oslo, Norway.

O. Singh Katar (1999), "Sustainable Development: Some Reflections", Indian Journal of

P. Agricultural Economics, Vol. 54 (1), New Delhi.

Q. Stanley Jayson (2004), "Development-induced Displacement and Resettlement", Forced Migration Online Research Guide, Refugee Studies Centre, University of Oxford.

R. Terminski Bogumil (2013), "Development-Induced Displacement and Resettlement: Theoretical Frameworks and Current

Geneva. http://dlc.dlib.indiana.edu/dlc/bitstream/handle/10535/8833/Bogumil\%20Terminski,\%20developmentInduced\%20Displacement\%20and\%20Resettlement.\%20Theoretical.

S. UNHCR (2007), "Forced migration and development", Global Forum on Migration and Development, Brussels.

T. UN Report, "Basic Principles and Guidelines on Development-Based Evictions and Displacement". http://www.ohchr.org/Documents/lssues/Housing/Guidelines_en.pdf.

U. World Commission on Dams (2000), "Dams and Development: a new framework for decision making", London: Earth Scan Publication.

V. World Bank Environment Department (WBED) (1996), "Resettlement and Development: The Bank wide Review of Projects Involving Involuntary Resettlement- 1986-1993", Environment Department Paper No. 032, Resettlement Series. Washington, D.C.: World Bank.http://www.wds.worldbank.org/servlet/WDSContentServer/WDSP/IB/1996/03/01/000009265_3980728143956/R endered/PDF/multi_page.pdf.

W. A Rew, E. Fisher, B. Pandey (200), "Addressing Policy Constraints and Improving Outcomes in Development-Induced Displacement and Resettlement Projects", University of Wales Swansea, pp. 91.

X. Forced Migration Review (2000), “Dilemmas of Development-Induced Displacement' special issue”, Vol. 12. http://www.fmreview.org/FMRpdfs/FMR12/fmr12contents.pdf. 